\title{
Primitive neuroectodermal tumor of the posterior mandible: A case report
}

\author{
Posterior mandibulanın primitif nöroektodermal tümörü: Olgu sunumu
}

\author{
Monal B. Yuwanati ${ }^{1}$, J V Tupkari ${ }^{2}$, Shubhangi Mhaske ${ }^{1}$, Pradnya Joshi ${ }^{2}$
}

\begin{abstract}
Primitive neuroectodermal tumor is a term used to describe a category of neoplasms of neuroectodermal origin with variable cell differentiation. These tumors arise in many places throughout the body. The chest wall, larynx, abdomen, and pelvis being the most common primary sites; in rare cases, they occur in the head and neck area. Only $3 \%$ of cases have been reported within the skull and jaws. In this report, a rare case of primitive neuroectodermal tumor in the left side posterior mandible in a young adult is described. J Clin Exp Invest 2013; 4 (1): 101-104
\end{abstract}

Key words: Neuroectodermal tumors, primitive, peripheral, oral cavity, mandible

\section{INTRODUCTION}

Neuroectodermal tumors occupy a predominant place in oncology. These tumors arise in many places throughout the body, with the chest wall, larynx, abdomen, and pelvis being the most common primary sites. Currently, this family of tumors is divided into two categories. Group (I) tumors, such as the pituitary adenomas and carcinoid tumors, represent tumors that show predominantly epithelial differentiation. The group (II) tumors, which include olfactory neuroblastoma, malignant melanoma, Ewing's sarcoma (EWS) and primitive neuroectodermal tumor display features that are predominantly neural and non-epithelial in origin. ${ }^{1}$

Primitive neuroectodermal tumor (PNET) is a term used to describe a category of neoplasm of neuroectodermal origin with variable cell differentiation. ${ }^{2}$ Earlier the term 'PNET' was used for tumor arising in central nervous system. More recently, the PNET concept has expanded to include histologically similar but peripherally located tumors referred to as peripheral primitive neuroectodermal tumors. ${ }^{3}$ These tumors are aggressive and have a propensity for local recurrence and metastasis especially

\section{ÖZET}

Primitif nöroektodermal tümör, nöroektodermal kaynaklı değişik hücre farklılaşması ile birlikte olan bir neoplazm kategorisini tanımlamak için kullanılan bir terimdir. Bu tümörler vücutta birçok yerden kaynak alır. Göğüs duvarı, larinks, karın ve pelvis en sık tutulan bölgeler olup, nadiren baş ve boyun bölgesinde oluşur. Olguların yalnızca \%3'ü kafatası ve çeneden köken alır. Bu raporda genç bir erişkinde mandibula sol arka kısmında gelişmiş nadir bir nöroektodermal tümör olgusu sunulmaktadır.

Anahtar kelimeler: Nöroektodermal tümörler, primitif, periferik, ağız içi, mandibula

in bone marrow, brain, lung and lymph node, but rarely to jaws and skull. Very few cases of PNET in the head and neck region have been reported in the literature. ${ }^{3}$

In recent years, the incidence of PNETs in head and neck areas have been increasingly reported, however, there is a paucity of reports of PNETs of the oral cavity. ${ }^{4,5,6,7}$ Emphasizing on the rarity of the lesion, a case of PNET of oral cavity in a young patient is reported.

\section{CASE REPORT}

A 17 years old male patient reported to Department of Oral Pathology, Government Dental College and Hospital, Mumbai, with chief complaint of rapidly growing painful mass on the buccal gingival in the left mandibular third molar region, since 10-12 days. The lower third molar on the affected side was extracted 7 days back due to pain and mobility. However, patient did not get relief.

Past medical history revealed surgery of right hand twice, however, the details of procedures, nature of surgery and histopathological diagnosis was

\footnotetext{
${ }^{1}$ Dept of Oral Pathology, People's Dental Academy collage and Hospital, Madhya Pradesh (MP), India

2 Dept of Oral Pathology, Government Dental College and Hospital, Mumbai-1, Maharashtra, India

Correspondence: Monal B Yuwanati, People's Dental Academy Collage and Hospital, Bhanpur bypass Road, Bhopal-462037, Madhya Pradesh (MP), India Email: monal9817@gmail.com Received: 08.02.2012, Accepted: 10.04.2012

Copyright (C) JCEI / Journal of Clinical and Experimental Investigations 2013, All rights reserved
} 
not available. Patient gave history of swelling on right hand since 5-6 years.

On general clinical examination, two soft tissue swellings between index and middle fingers of right hand were noticed which resulted in disfigurement.

Extra-oral examination of face showed no obvious abnormality. Intra-oral clinical examination revealed a soft fleshy mass of approximately $3 \times 2 \mathrm{~cm}$ in the lower left third molar region extending in the retromolar region (Figure 1). Lateral oblique radiograph of mandible did not reveal any abnormality (Figure 2). Incisional biopsy from the third molar region was taken.

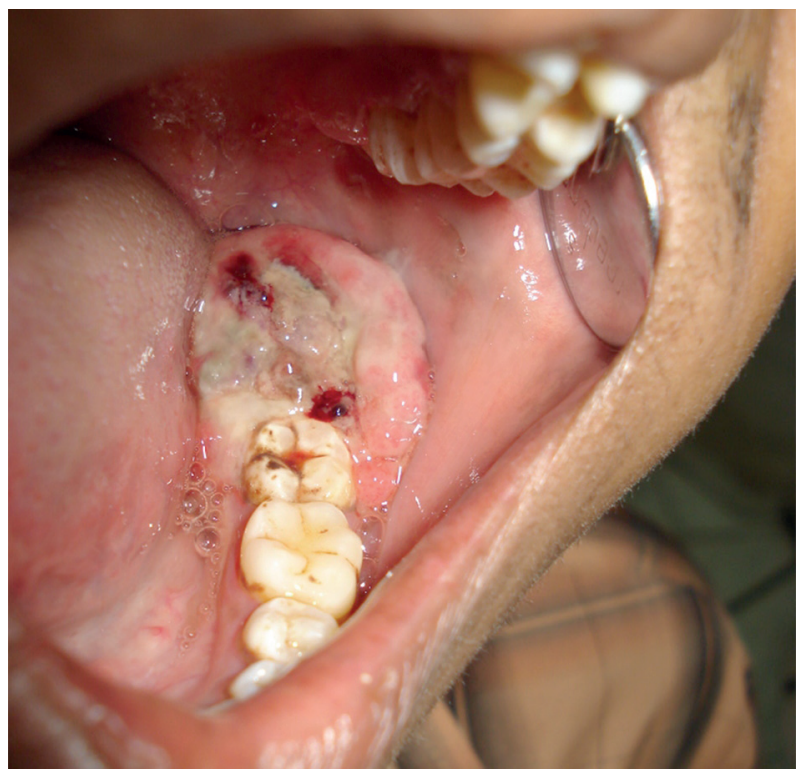

Figure 1. A soft fleshy mass measuring about $3 \times 2 \mathrm{~cm}$ in the lower left side in third molar and retromolar region

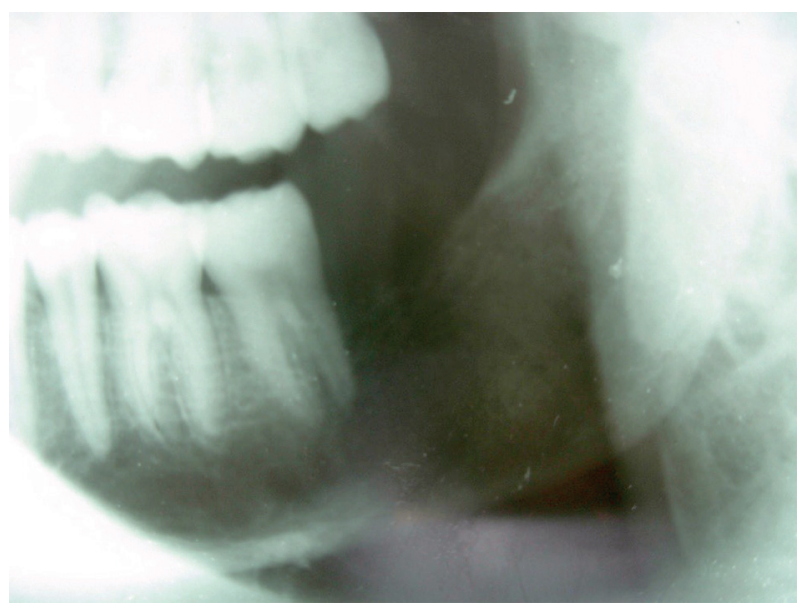

Figure 2. Lateral oblique radiograph of mandible did not reveal any abnormality
On histopathological examination, H\&E stained section showed sheets of proliferating hyperchromatic, small, round cells with ovoid nuclei with scanty eosinophilia cytoplasm. The stroma was scanty, few connective tissue septae and some areas of hemorrhage were seen (Figure 3). Suggestive of small round cell tumour such as primitive neuroectodermal tumour, Ewing sarcoma, metastatic neuroblastoma, malignant lymphoma, small cell osteosarcoma, embryonal rhabdomyosarcoma.

Immunohistochemistry was done for confirmation and typing of lesion. Tumour tissue was reactive to S100 (Figure 4), vimentin and CD99 and negative for pancytokeratin, leucocyte common antigen, chromogranin and HMB-45. The histopathology and immunohistochemistry findings were suggestive of primitive neuroectodermal tumour. The patient was referred to higher centre for further evaluation and treatment.

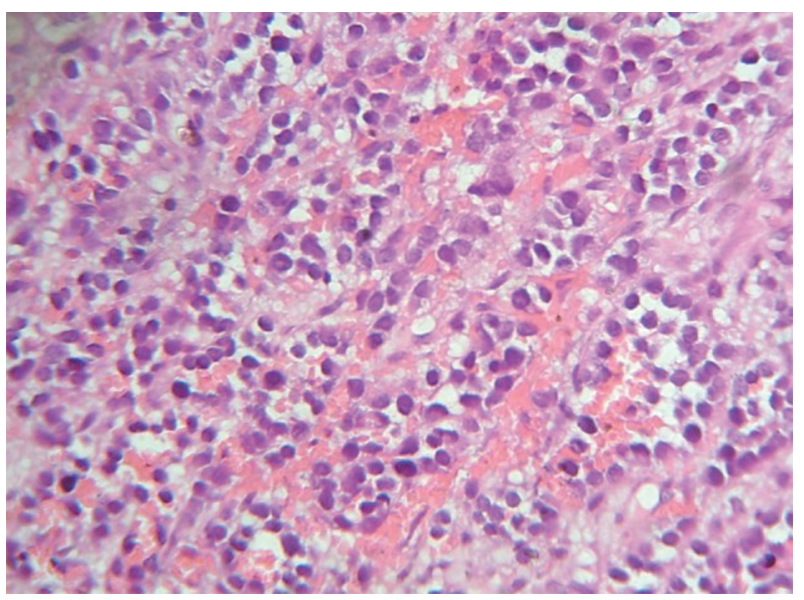

Figure 3. Microscopic examination of soft tissue specimen showed sheets of proliferating small, hyperchromatic, round cells with ovoid nuclei and scarce pink cytoplasm

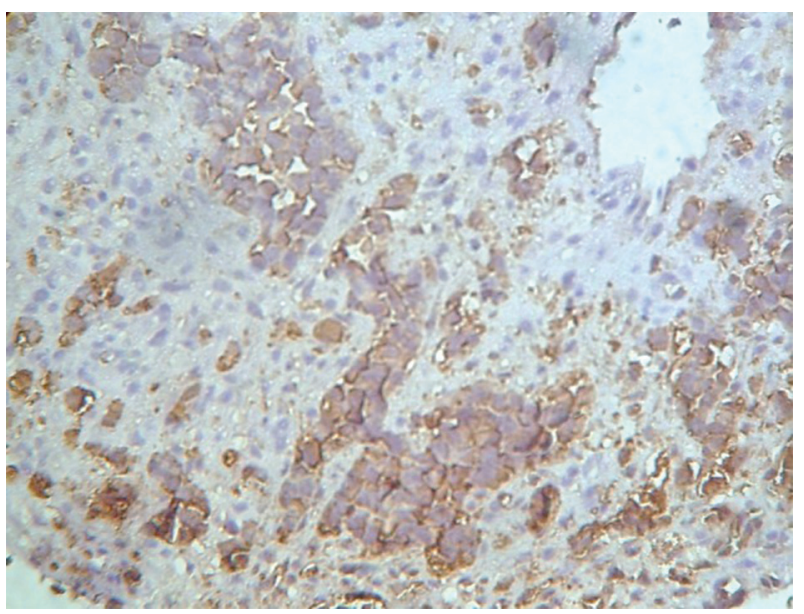

Figure 4. Tumor tissue was reactive to $\mathrm{S} 100$ 


\section{DISCUSSION}

The term 'PNET' was first introduced by Hart and Earle $^{7}$ in 1973 with reference to a class of neoplasm occurring in children and composed of small cells showing various signs of maturation along neural, glial or (more rarely) mesodermal lines. PNET affects primarily white and Hispanic young people and is extremely rare in individuals of African or Asian origin. ${ }^{8}$ The reason for this striking ethnic distribution is not known. Based on the site of involvement, the PNET are grouped as central and peripheral tumors. Central PNET such as medulloblastoma originates in the brain and spinal cord, whereas peripheral PNETs include adrenal and extra-adrenal neuroblastomas of soft tissues, nerve, and bone.

The peripheral Primitive Neuroectodermal Tumor first recognized by Arthur Purdy Stout ${ }^{9}$ in 1918, is a member of the family of "small round-cell tumors" this was subsequently designated as PNET. It is seen involving any bone, however it predominately involves central and axial skeleton as well as the diaphysis of long bones. They are often associated with pain and swelling.

The actual incidence of PNET is difficult to ascertain. Only $3 \%$ of cases have been reported within the skull and jaws. ${ }^{10}$ It primarily affects children and young adults ${ }^{5}$ without any sex predilection. ${ }^{10}$ It usually occurs in the chest, pelvis and retroperitonium; but may also be seen involving head and neck area such as skull, orbit, masseter muscle ${ }^{11}$ and maxilla. ${ }^{10,12}$ The majority of the tumors are localized in the mandibular symphysis region. Stout reviewed twenty six cases of PNET of head and neck region of which eleven tumors were localized to the mandible. Jurgens et al. ${ }^{13}$ carried out a retrospective analysis of forty two cases, of which only four were localized to the head and neck region. Two of four tumors had bone involvement however; the authors did not specify the exact location of tumors. The usual clinical manifestations include pain and swelling, however, it depends on the site of involvement. Intraoral PNET resembles commonly seen oral lesions such as, pyogenic granuloma; Peripheral Giant cell Granuloma, lipoma and hemangioma. Minor salivary gland can also resemble to soft tissue tumor. ${ }^{14}$

The definitive diagnosis of PNET depends on histology and Immunohistochemistry. PNET is one of the group of neoplasms collectively referred to as "small round cell tumors of childhood", which include neuroblastomas, rhabdomyosarcoma, lymphoma, small round cell Osteosarcoma and the Ewing family of tumours. Histopathologically, these neoplasms consist of narrow sheets of poorly differentiated cells with uniform, round or oval nuclei and scant cytoplasm. However, it is not easy to distinguish PNET morphologically from other small round cell tumours and hence IHC is necessary for confirmation of the diagnosis.

The Ewing sarcoma family of tumors that can occur in the head and neck region comprises osseous and extraosseus variety of Ewing sarcoma (EES) and peripheral primitive neuroectodermal tumor (pPNET). ${ }^{6}$ Discrimination criteria have been proposed to aid in diagnosis of PNET. ${ }^{15}$ Features are (1) well defined histological evidence of HomerWright or Flexner-Wintersteiner rosettes. (2) Immunoreactivity to two or more neural markers, and/ or (3) ultra-structural transmission electron micrographic evidence of neural differentiation and neurosecretory granules.

Osteosarcoma has closest resemblance to PNET. However, Homer-rosettes pattern and neuroendocrine markers along with the lack of osteoid would tend to rule out osteosarcoma. Neuroblastoma, a tumor that generally develops in the adrenal medulla or along the sympathetic ganglion chain, generally has increased catecholamine and it does not stain for CD99. Lymphoma shows positive reactivity for CD45 whereas Rhabdomyosarcoma (RMS) stains positive for desmin and myogenin. Pancytokeratin staining and the presence of perinuclear dot like desmin staining pattern generally characterize Desmoplastic Small round cell tumor (DSRCT). EWS closely resemble the PNET, microscopically but tends to have less distinct Homer-Wright rosettes, cells with paler cytoplasm and increased PAS + staining relative to the biopsy sample. There are several antibody neural markers (NSE, S-100, Leu-7, chromogranin, neurofilaments) which specifically labeled in PNET and are negative in Ewing's sarcoma. Positive staining for vimentin and CD 99 plays a key role differentiation of PNET from other small round cell tumors. ${ }^{4} \mathrm{PCR}$ molecular analysis is also helpful for making the diagnosis of ES/PNET. However, the diagnosis of PNET has been largely a process of exclusion.

PNET has a tendency for recurrence and to metastasis, especially to bone marrow, brain, lung and lymph node with lung being the most common site. ${ }^{14}$ Metastasis have been observed at the time of diagnosis in up to $31 \%$ of patients, reflecting the aggressiveness of these tumors. ${ }^{10}$ Metastasis to oral cavity ${ }^{7}$ from the primary lesion located at other sites is uncommon.

Due to the relative paucity of PNET cases, no standardized treatment regimes have been estab- 
lished. However, as a result of and availability of advanced technology and research in the field of diagnostic and therapeutic oncology, identification of more effective treatment strategies and improved prognoses have been achieved over the past few decades. ${ }^{15}$ The recommended treatment consists of a combination of chemotherapy, surgery, radiation therapy. Although PNET is considered radiosensitive, radiation is generally administered as an adjuvant therapy in cases of incomplete surgical re-section or where there are close tumor margins. Frequently used chemotherapeutic agents include cyclo-phosphamide, ifosfamide, vincristine, doxorubicin, and Dactinomycin. Successful treatment requires close cooperation among the surgeons and medical and radiation oncologists to ensure the most effective management approach. Local Surgical removal of the primary lesion along with combination of systemic chemotherapy to control subclinical micro-metastases should be considered for the treatment of PNET. Periodic follow up of the patient is recommended.

The prognosis of PNET is poor; with 2-year survival rate in only $65 \%$ cases, after diagnosis, regardless of treatment modalities applied..$^{15}$ Poor prognostic factors for PNET include patient more than ten years of age, bony infiltration and bone marrow metastasis, radiation therapy at doses greater than $5 \mathrm{~Gy}$, and high doses chemotherapy with hematopoietic regimen.

In conclusion, PNET is a rare but highly aggressive tumor of head and neck region. It is characterized by ill-defined presentation and rapid growth. To date, there are no clinical or radiological modalities that ensure early detection of this rare tumor. However, histopathology, immunohistochemistry are keys to its diagnosis. Recently the numbers of cases of PNET reported are increasing gradually due to awareness. But still, there is a paucity of PNET. It should be included in the differential diagnosis of rapidly growing lesions of the mouth.

\section{REFERENCES}

1. Mills S. Neuroectodermal neoplasms of head and neck with emphasis on neuroectodocrine carcinoma. Mod Pathol 2002;5:264-278.
2. Chowdhury K, Manoukian JJ, Rochon L, et al. Extracranial primitive neuroectodermal tumor of the head and neck. Arch Otolaryngol Head Neck Surg 1990;116:475-478.

3. Helsel JC, Mrak RE, Hanna E et al. Peripheral primitive neuroectodermal tumor of the parotid gland region: report of a case with fine-needle aspiration findings. Diag Cytopathol 2000;22:161-166.

4. Hyun CB, Lee YR, Bemiller TA. Metastatic peripheral primitive neuroectodermal tumor (PNET) masquerading as liver abscess. J Clin Gastroenterol 2002;35:9397.

5. Jones JE, McGill T. Peripheral primitive neuroectodermal tumors of the head and neck. Arch Otolaryngol Head Neck Surg 1995;121:1392-1395.

6. Kao SY, Yang J, Yang AH, et al. Peripheral primitive neuroectodermal tumor of the maxillary gingivae with metastasis to cervical lymph nodes: report of a case. J Oral Maxillofac Surg 2002;60:821-825.

7. Votta TJ, Fantuzzo JJ, Boyd BC. Peripheral neuroectodermal tumor associated with the anterior mandible: a case report and review of the literature. Oral Surg Oral Med Oral Path Oral Radiol Endod 2005;105:592-597.

8. Garcia AG, Pereira C. Primitive neuroectodermal tumor of the upper jaw. J Oral Maxill Fac Surg 1999; 57: 616-623.

9. Pereira CM, Alves F. Mouth metastasis of peripheral primitive neuroectodermal tumor, Oral Disease 2005;11:44-45.

10. Stout AP. A tumor of the ulnar nerve. Proc NY Pathol Soc 1918;12:2-12.

11. Kahn HJ, Thorner PS. Monoclonal antibody MB2: A potential marker for Ewing's sarcoma and primitive neuroectodermal tumor. Pediatr Pathol 1989;9:153162.

12. de Alava E, Gerald WL. Molecular biology of the Ewing's sarcoma/primitive neuroectodermal tumor family. J Clin Oncol 2000;18:204-213.

13. Jurgens $H$, Bier V. Malignant peripheral neuroectodermal tumors a retrospective analysis of 42 patients. Cancer 1988;61:349-357.

14. Hollis LJ, Poole S. Primitive neuroectodermal tumor of masseter muscle. J Laryngol Otol 1996; 27:1179.

15. Jurgens H, Bier V, Harma D, Beck J. Malignant peripheral neuroectodermal tumors: a retrospective analysis of 42 patients. Cancer 1988;61:349-357. 